

\title{
Policy Selectivity Forgone: Debt and Donor Behavior in Africa
}

\author{
Nancy Birdsall, Stijn Claessens, and Ishac Diwan ${ }^{\square}$
}

Center for Global Development

Working Paper No. 17

(Forthcoming in World Bank Economic Review)

November 2002

Updated October 2003

\section{JEL Classifications: O11, O19, F34, F35 \\ Key words: debt relief, foreign aid, low-income countries, and international organizations}

\footnotetext{
Nancy Birdsall is President Center for Global Development. Her email address is nbirdsall@cgdev.org. Stijn Claessens is Professor of International Finance Policy, University of Amsterdam. His email address is stijn@fee.uva.nl. Ishac Diwan is Country Director for Ethopia and Sudan, World Bank. His email is idiwan@worldbank.org. The authors are grateful to Jean-Claude Berthelemy, Alan Gelb, Bernhard Gunter, Ratna Sahay, and Axel van Trotsenburg and to various participants in seminars at the World Bank, the Carnegie Endowment for International Peace, the 2001 World Bank Economists' Forum, the 2001 WIDER Debt Relief Conference, and the 2003 American Economic Association meeting for their comments. They thank François Bourguignon and three referees for their extensive comments, Ying Lin (World Bank) for his excellent work with the data, and Brian Deese for other research help. The article was previously entitled: "Will HIPC Matter? The Debt Game and Donor Behavior in Africa." Address questions and comments to the corresponding author: Stijn Claessens, Finance Group, University of Amsterdam Roetersstraat 11, 1018 WB Amsterdam, The Netherlands (stijn@fee.uva.nl).
} 
A large literature has developed in recent years on country factors and other factors that influence the effectiveness of aid and of the development aid business more generally. Two major findings have emerged. First, aid is more effective when the recipient country's policy and institutional environment satisfies some minimal criteria. Second, aid and debt relief have not been targeted particularly toward countries with adequate policies and institutions (Burnside and Dollar 2000). ${ }^{1}$ In this article, we concentrate on understanding the dynamics behind the second finding. To do so, we analyze the donor and official creditor side of the aid process. Our specific hypothesis is that the growing debt of poor countries over the last two decades and the composition of that debt have affected the granting of new loans and grants by donors and official creditors.

Analyzing the behavior of donors and creditors as it relates to the accumulated debt burden is important because it can shed light on a critical policy question. Will the official program of debt reduction for Heavily Indebted Poor Countries (HIPCs) not only reduce debts but also affect future donor behavior, particularly the ability and willingness of donors to direct aid to its best uses? Or will more debt reduction simply invite another round of business-as-usual (new loans and new debt accumulation) implicated in the first debt buildup?

To address these questions, we investigate donor and creditor behavior using data on net transfers for 37 Sub-Saharan countries over the 1980s and 1990s. Just as others have documented, our analysis confirms that the quality of a country's policy framework has mattered little in determining overall net transfers. Importantly, we find that the buildup of debt stocks owed to the multilateral creditors hindered the targeting of resource flows to countries that had better policies and improved institutional environments. We find in particular that more-indebted countries received more net transfers-and that among countries highly indebted to multilaterals, those with policies below the median in quality received on average some 2 percentage points of GDP more in net transfers over the period. We also find that donors are selective for country policies in low debt countries but not so in high multilateral debt countries. These findings are robust to the use of different estimation techniques and alternative measures for the quality of policy.

The findings suggest that the buildup of debt, especially to multilaterals, has undermined the ability of the donors to be selective for country policies - that is, to transfer less where the policy setting is poor. They imply that debt reduction for high multilateral debt countries can allow the behavior of the donor community to shift to a low debt regime mode, a regime that in the past has allowed selectivity. Debt reduction can be interpreted in short as a way "out" for a donor community otherwise locked into a pattern of nonselectivity in the high multilateral debt countries.

${ }^{1}$ The first finding is not without controversy, however, particularly regarding the robustness of the connection between "good policy" and aid effectiveness (Hansen and Tarp 2001). See Hansen and Tarp (2000) for a review of the literature, and World Bank (1998) for further information on aid effectiveness. 
Section I describes the overall setting for development assistance and documents the accumulation of debt by Sub-Saharan countries over the 1980s and 1990s to different classes of creditors. Section II describes the data used and provides the major trends and raw statistics. Section III specifies the hypothesis, describes the empirical analysis, and discusses the major findings. Section IV concludes.

\section{DeVelopment Assistance ANd DebT ACCuMUlation in AfRicA, 1980s AND 1990s}

Over the last 25 years Sub-Saharan countries have been major recipients of overseas development assistance. Aid in the form of grants and loans from bilateral and multilateral donors has amounted to about $\$ 350$ billion dollars (in nominal terms). In some countries gross aid flows were 60 percent or more of GDP in some years; in many countries flows often exceeded the government's tax revenues. With a few exceptions, these countries have had low rates of per capita GDP growth. Despite high levels of lending and grant programs, the growth rate of per capita GDP for the region as a whole was negative over the last two decades (about -2 percent a year in the 1980s and -1 percent in the 1990s). Average GDP per capita in constant prices was lower in 2000 than in 1960. And the number and proportion of poor people actually increased: 40 percent of the 600 million people in Sub-Saharan Africa lived on less than \$1 a day in 2000 (World Bank 2000).

Meanwhile, much of the high level of development assistance took the form of loans, producing a growing stock of debt—from about $\$ 60$ billion in 1980 to $\$ 230$ billion in 2000. Annual debt service paid also increased, from an average of $\$ 6$ billion a year in the early 1980s to about $\$ 11$ billion in the late 1990s. Growth in debt service was much less than growth in debt, however, due to debt restructuring and increases in the concessionality of resources provided. In the 1990s especially, repeated rounds of debt rescheduling and debt service relief by the official donor community —and an increase in the proportion of donor transfers as grants—-kept debt service from rising more.

While many other countries have had external debt problems, two features of the debt problem in Africa are notable. First, because of the preponderant role of official creditors and donors (as opposed to commercial creditors), net transfers have been always positive and large. Total disbursements in the form of new loans and grants have always exceeded countries' actual debt service. Indeed net transfers-the difference between new disbursements and debt service paid-have been 10 percent or more of GDP for most countries for the two decades. Second, the proportion of total debt owed to the IMF, World Bank, and other multilaterals (African Development Bank, European Investment Bank) has been constantly growing as bilateral donors switched from loans to grants and increasingly forgave outright portions of debt owed them. Between 1980 and 1998 the share of multilateral debt in total debt increased from about one-seventh of total debt to 
almost one-third, and the share of the multilaterals in total debt service increased from about one-tenth to one-third. ${ }^{2}$

These features highlight the important differences between the debt problems of the African countries today and those of Latin American and other middle-income countries in the 1980s, extensively analyzed (see Eaton and Fernandez 1995 for a review of this literature). Most debts of the Latin American countries were then due to commercial rather than official creditors. Each commercial creditor was individually interested in maximizing the value of its claim on the country. This desire to extract payments led to a "tax" on the country, a debt overhang. High levels of debt were leading to disincentives to adjust economic policies, and new investors were deterred from committing resources to the country (Diwan and Rodrik 1992). The literature then stressed the potential beneficial effects of a reduction in the face value of debt for creditors because it could increase the incentives for a debtor to adjust and enhance a country's ability to attract new (type of) investors and fresh funds. Ex-post, the debt overhang was resolved through debt reduction (the Brady plan) that seems to have had some of these beneficial effects (Claessens and Diwan 1994).

The situation of the African countries is quite different (Claessens and others 1997). Although the debt stocks were rising, they did not impose any actual debt servicing burden because countries received large positive net transfers and did not need to repay their creditors. ${ }^{3}$ But with debt service payments rising, especially to multilaterals, higher and higher disbursements by donors (the multilaterals themselves or the bilaterals) were needed to maintain net transfers. The rising debt levels and the increase in the share of the multilaterals meant that by the mid-1990s the donors and creditors were caught in a debt trap-not the indebted countries. The donors wanted to avoid having the indebted countries, among the poorest in the world, fall behind in debt service to the multilaterals. Arrears to the multilaterals would have meant the curtailment of future lending by not only the multilaterals but by all other donors because continuing aid flows required an active multilateral lending program. And from the donors' point of view, arrears would make visible the failure of the past aid transfers.

As debt stock considerations started to drive new disbursements, the quality of policy and degree of poverty in countries became less relevant. The need to maintain high new disbursements in highly indebted countries may have meant that donors no longer had enough freedom to differentiate new disbursements by the quality of policy and degree of poverty. In other words, indebtedness took some of the donor community's

${ }^{2}$ Total debt service paid also increased, from about 7 to 15 percent of the value of exports.

3 The fact that net transfers have generally been positive has not been sufficiently taken into account in the oft-heard arguments that countries are spending more on debt service than on social programs. Birdsall and Williamson (2002) point out that it may, however, still be true that the local taxes needed to pay debt service are not really offset by the often-tied aid transfers for specific projects. 
ability to be selective for policy and poverty, and aid flows started to respond more to debt stocks, less to policy and poverty. ${ }^{4}$

\section{DATA AND GENERAL ANAlysis OF DONOR BEHAVIOR}

To assess creditor and donor behavior, we analyze debt indicators and net transfers for a sample of countries in Sub-Saharan Africa over 1977-98. We want to assess donor behavior toward countries in the region independent of whether countries eventually became HIPC-eligible or not, a classification that occurred around 1998, and without the classification affecting donor behavior. We therefore use a sample that includes both HIPC and non-HIPC countries and stop our analysis in 1998, avoiding any sample selection problem. We include in our analysis the 37 Sub-Saharan countries with all necessary data. Some countries (including Eritrea, Angola, Somalia, and Tanzania) are excluded for lack of data in many individual years. Of the 34 African countries eligible for HIPC treatment (in 2002), 29 are included in our sample of 37 (table 1). ${ }^{5}$

${ }^{4}$ Easterly (1999) develops a model to explain why countries with certain characteristics end up with high debt. His model has the strong implication that countries pursue bad policies to receive future debt reduction. The model does not examine the behavior of the creditors to these countries, however, in relation to the debt composition.

${ }^{5}$ The HIPC sample includes mainly Sub-Saharan countries. Since the bulk of aid flows has also gone to Sub-Saharan countries, we focus on the behavior of donors in these countries. 
Table 1. Sample Countries

\begin{tabular}{ll}
\hline HIPC Debt Initiative & Non-HIPC \\
\hline Benin & Botswana \\
Burkina Faso & Gabon \\
Burundi & Lesotho \\
Cameroon & Mauritius \\
Central African Republic & Nigeria \\
Chad & Seychelles \\
Comoros & Swaziland \\
Congo & Zimbabwe \\
Congo, Dem. Rep & \\
Côte d'Ivoire & \\
Ethiopia & \\
The Gambia & \\
Ghana & \\
Guinea & \\
Guinea-Bissau & \\
Kenya & \\
Liberia & \\
Madagascar & \\
Malawi & \\
Mali & \\
Mauritania & \\
Niger & \\
Rwanda & \\
Senegal & \\
Sierra Leone & \\
Sudan & \\
Togo & \\
Uganda & \\
Zambia & \\
29 & \\
Note: HIPC classification as of fall 2002. & \\
Source: World Bank, various years, Global Development Finance. \\
\end{tabular}

\section{Data}

The variable of interest for our analysis is the amount of net transfers a country receives from abroad related to debt or grants - that is, the amount of net movement of real resources to the country from official sources on account of debt or grants. We thus exclude from our analysis flows related to foreign direct, portfolio and other nondebt investments. Net transfers are defined, in accord with the World Bank's Global Development Finance (GDF), as the amount of resources the countries receive in the form of grants and new debt disbursements net of repayments on old debt. In other words,

$$
\text { (1) } N T=G+N B-(P+R)=G+N B-T D S
$$


where $N T=$ net transfers, $G=$ the amount of grants (free gifts) the country receives, $N B=$ new debt disbursements, $P=$ principal repayment on existing debt, $R=$ interest payment on existing debt, and $T D S=$ total debt service paid, the sum of principal repayment $P$ and interest payments $R$. We restrict ourselves to resources directed to the government from mainly official (nonprivate) sources. These sources include the World Bank, the IMF, and other multilaterals as well as bilateral donors and donor agencies.

All data on debt and net transfers are from the World Bank's Global Development Finance statistics. This data set, published annually, relies on debtors' reports, crossverified with creditor sources. It provides the statistics on debt, disbursements and repayments. In accord with these data, all amounts related to debt are on a cash-basisthat is, they represent actual payments, not scheduled amounts, so that arrears or debt and debt service reduction do not confound the data. Global Development does not collect data on grants itself, but relies on donors' official development assistance (ODA) and Organisation for Economic Co-operation and Development-Development Assistance Committee (OECD-DAC) reports for the grant information.

Grants do not give rise to repayment obligations and are thus not affected by the difference between obligations due and actual payments, the arrears. The grants data do include, however, some elements of official debt and debt service reduction because donors have included debt forgiveness in their reported figures. In particular, the amount of grants reported by donors includes some debt forgiveness that may not imply any actual net transfers to the debtor. ${ }^{6}$ The quality of the data on official debt reduction is known to be very poor, however, and we cannot correct the grants figure to derive a more accurate actual net resource figure (see Renard and Cassimon 2001).

We limit the impact of outliers by dropping observations for years when net transfers to a country were more than 60 percent of GNP (we also used a lower threshold of 30 percent but results were not qualitatively different). Nor do we always have all the independent variables that we later need in our regressions. This means that some country-year observations drop out as well. For our 37 countries, we end up with 848 country-year observations.

\section{Indebtedness Categories}

We turn now to a systematic analysis of donor and creditor behavior, addressing some specific questions. Were donors' net transfers to countries related to recipient countries' debt stock? Were donors and creditors providing higher net transfers to countries with better policies? For a given policy framework, were donors transferring more to countries with higher levels of poverty? In short, was there selectivity by donors

${ }^{6}$ This could lead to a negative relationship between net transfers and the stock of debt, since debt stocks are reduced and while grants are higher, which would bias downward the coefficients on debt stock in our regression analysis of net transfers. As we find positive coefficients, any misreporting only strengthens our results. 
and creditors as a function of countries' (changing) policies and degree of poverty? Or did the mounting debt stock and the resulting debt "crisis" lock donors into defensive lending to high debt countries, depriving them of selectivity and leverage for recipient country policies?

We start by dividing our sample of country-year observations into three subgroups of indebtedness, first distinguishing low and high debt countries, and then creating within the high debt group a further subdivision into low and high multilateral debt group (table 2). Specifically, each country-year observation is considered a low (or high) debt regime if the country's debt to GDP ratio in that year is below (or above) 62.8 percent (the median debt to GDP ratio of the whole sample). The high debt group is further subdivided into low and high multilateral debt groups, according to whether the share of multilateral debt in total debt for that country and year is below or above 41.2 percent (the median share of multilateral debt in total debt for the whole sample). In other words, the high debt, low multilateral category comprises country-year observations where the total debt to GDP ratio is greater than 62.8 percent, but the share of multilateral debt in total debt is less than 41.2 percent, while the high debt, high multilateral category constitutes those country-year observations in which the total debt to GDP ratio is also greater than 62.8 percent, but the share of multilateral debt in total debt is greater than 41.2 percent. The high debt, high multilateral category comprises country-year observations in which the total debt to GDP ratio is also greater than 63.8 percent, but the share of multilateral debt in total debt is greater than 41.2 percent.

The total sample in this classification varies slightly, between 34 and 37, because debt data are not available for each year for each country. The size of the subsamples also varies over time. The number of low debt countries was 32 in 1977, but dropped to only 9 in 1998. For the whole group the number of high debt countries grew sharply, from 2 in 1977 to 27 in 1998. The number of high multilateral debt countries in the high debt group increased sharply, from 0 in 1977 to 20 in 1998. The number of low multilateral debt countries in the high debt group grew from 2 in 1977 to 14 in 1987 and then dropped to 7 in 1998. 
Table 2. Debt Classification of Countries, 1977-98

\begin{tabular}{|c|c|c|c|c|c|c|c|c|c|c|c|c|c|c|c|c|c|c|c|c|c|c|}
\hline untry & 1977 & 1978 & 1979 & 1980 & 1981 & 1982 & 1983 & 1984 & 1985 & 1986 & 1987 & 1988 & 1989 & 1990 & 1991 & 1992 & 1993 & 1994 & 1995 & 1996 & 1997 & 1998 \\
\hline Benin & $L$ & $L$ & $L$ & $\bar{L}$ & $\mathrm{~L}$ & $\bar{L}$ & $\mathrm{~L}$ & $\mathrm{~L}$ & $\mathrm{ML}$ & $L$ & $\mathrm{ML}$ & $L$ & $\mathrm{ML}$ & $\mathrm{MH}$ & $\mathrm{MH}$ & $\mathrm{MH}$ & $\mathrm{MH}$ & $\mathrm{MH}$ & $\mathrm{MH}$ & $\mathrm{MH}$ & $\mathrm{MH}$ & $\mathrm{MH}$ \\
\hline Botswana & L & L & L & $\mathrm{L}$ & L & L & $\mathrm{L}$ & L & $\mathrm{L}$ & L & L & L & L & L & L & L & L & L & $\mathrm{L}$ & L & L & $\mathrm{L}$ \\
\hline Burkina Faso & L & L & L & L & L & L & L & L & L & L & L & L & L & L & L & L & L & L & L & L & L & L \\
\hline Burundi & L & L & L & L & L & L & L & L & L & L & $\mathrm{MH}$ & $\mathrm{MH}$ & $\mathrm{MH}$ & $\mathrm{MH}$ & $\mathrm{MH}$ & $\mathrm{MH}$ & $\mathrm{MH}$ & $\mathrm{MH}$ & $\mathrm{MH}$ & $\mathrm{MH}$ & $\mathrm{MH}$ & $\mathrm{MH}$ \\
\hline Cameroon & $\mathrm{L}$ & $\mathrm{L}$ & L & L & L & L & L & L & L & L & L & $\mathrm{L}$ & L & L & L & $\mathrm{L}$ & $\mathrm{L}$ & $\mathrm{ML}$ & $\mathrm{ML}$ & ML & $\mathrm{ML}$ & ML \\
\hline Central African Republic & L & L & L & L & L & L & L & L & L & L & L & L & L & L & L & L & L & $\mathrm{MH}$ & $\mathrm{MH}$ & $\mathrm{MH}$ & $\mathrm{MH}$ & $\mathrm{MH}$ \\
\hline Chad & L & L & L & L & L & L & L & L & L & L & L & L & L & L & L & L & L & $\mathrm{MH}$ & L & L & $\mathrm{MH}$ & $\mathrm{MH}$ \\
\hline Comoros & L & L & $\mathrm{L}$ & L & $\mathrm{L}$ & $\mathrm{MH}$ & $\mathrm{MH}$ & $\mathrm{MH}$ & $\mathrm{MH}$ & $\mathrm{MH}$ & $\mathrm{MH}$ & $\mathrm{MH}$ & $\mathrm{MH}$ & $\mathrm{MH}$ & $\mathrm{MH}$ & $\mathrm{MH}$ & $\mathrm{MH}$ & $\mathrm{MH}$ & $\mathrm{MH}$ & $\mathrm{MH}$ & $\mathrm{MH}$ & $\mathrm{MH}$ \\
\hline Congo, Dem. Rep. & L & L & $\mathrm{L}$ & L & L & L & L & $\mathrm{ML}$ & ML & $\mathrm{ML}$ & $\mathrm{ML}$ & $\mathrm{ML}$ & ML & $\mathrm{ML}$ & ML & $\mathrm{ML}$ & $\mathrm{ML}$ & $\mathrm{ML}$ & $\mathrm{ML}$ & ML & ML & ML \\
\hline Congo, Rep. & L & ML & ML & ML & ML & ML & ML & ML & ML & $\mathrm{ML}$ & ML & ML & $\mathrm{ML}$ & ML & ML & $\mathrm{ML}$ & $\mathrm{ML}$ & ML & ML & ML & ML & $\mathrm{ML}$ \\
\hline Côte d'Ivoire & L & L & L & ML & ML & ML & ML & ML & ML & ML & ML & ML & $\mathrm{ML}$ & ML & ML & ML & ML & ML & ML & ML & $\mathrm{ML}$ & ML \\
\hline Ethiopia & . & . & . & . & L & L & L & ML & ML & ML & $\mathrm{ML}$ & ML & $\mathrm{ML}$ & $\mathrm{ML}$ & ML & ML & ML & ML & $\mathrm{ML}$ & ML & ML & ML \\
\hline Gabon & L & L & L & L & L & L & L & L & L & L & $\mathrm{ML}$ & ML & $\mathrm{ML}$ & L & ML & $\mathrm{ML}$ & ML & $\mathrm{ML}$ & ML & ML & ML & ML \\
\hline Gambia, The & L & L & $\mathrm{L}$ & L & $\mathrm{MH}$ & $\mathrm{MH}$ & $\mathrm{MH}$ & $\mathrm{MH}$ & $\mathrm{MH}$ & $\mathrm{MH}$ & $\mathrm{MH}$ & $\mathrm{MH}$ & $\mathrm{MH}$ & $\mathrm{MH}$ & $\mathrm{MH}$ & $\mathrm{MH}$ & $\mathrm{MH}$ & $\mathrm{MH}$ & $\mathrm{MH}$ & $\mathrm{MH}$ & $\mathrm{MH}$ & $\mathrm{MH}$ \\
\hline Ghana & L & L & L & L & L & L & L & L & L & L & $\mathrm{MH}$ & L & L & L & L & $\mathrm{MH}$ & $\mathrm{MH}$ & $\mathrm{MH}$ & $\mathrm{MH}$ & $\mathrm{MH}$ & $\mathrm{MH}$ & $\mathrm{MH}$ \\
\hline Guinea & . & . & . & . & . & . & . & . & . & ML & ML & ML & ML & ML & ML & $\mathrm{ML}$ & $\mathrm{MH}$ & $\mathrm{MH}$ & $\mathrm{MH}$ & $\mathrm{MH}$ & $\mathrm{MH}$ & $\mathrm{MH}$ \\
\hline Guinea-Bissau & L & L & L & . & ML & ML & $\mathrm{MH}$ & ML & . & ML & . & . & . & $\mathrm{MH}$ & $\mathrm{MH}$ & $\mathrm{MH}$ & $\mathrm{MH}$ & $\mathrm{MH}$ & $\mathrm{MH}$ & $\mathrm{MH}$ & $\mathrm{MH}$ & $\mathrm{MH}$ \\
\hline Kenya & $\mathrm{L}$ & L & $\mathrm{L}$ & L & L & L & L & L & $\mathrm{MH}$ & L & $\mathrm{MH}$ & $\mathrm{MH}$ & $\mathrm{MH}$ & $\mathrm{MH}$ & $\mathrm{MH}$ & $\mathrm{MH}$ & $\mathrm{MH}$ & $\mathrm{MH}$ & $\mathrm{MH}$ & $\mathrm{MH}$ & L & L \\
\hline Lesotho & L & L & $\mathrm{L}$ & L & L & L & L & L & L & L & L & L & L & L & L & L & L & L & L & L & L & $\mathrm{MH}$ \\
\hline Liberia & L & L & $\mathrm{L}$ & L & ML & $\mathrm{MH}$ & $\mathrm{MH}$ & $\mathrm{MH}$ & $\mathrm{MH}$ & $\mathrm{MH}$ & $\mathrm{MH}$ & . & . & . & . & . & . & . & . & . & . & . \\
\hline Madagascar & $\mathrm{L}$ & L & $\mathrm{L}$ & L & L & L & L & ML & ML & ML & $\mathrm{ML}$ & ML & $\mathrm{ML}$ & $\mathrm{ML}$ & $\mathrm{MH}$ & $\mathrm{MH}$ & $\mathrm{MH}$ & $\mathrm{MH}$ & $\mathrm{MH}$ & $\mathrm{MH}$ & $\mathrm{MH}$ & $\mathrm{MH}$ \\
\hline Malawi & L & L & L & L & $\mathrm{MH}$ & $\mathrm{MH}$ & $\mathrm{MH}$ & $\mathrm{MH}$ & $\mathrm{MH}$ & $\mathrm{MH}$ & $\mathrm{MH}$ & $\mathrm{MH}$ & $\mathrm{MH}$ & $\mathrm{MH}$ & $\mathrm{MH}$ & $\mathrm{MH}$ & $\mathrm{MH}$ & $\mathrm{MH}$ & $\mathrm{MH}$ & $\mathrm{MH}$ & $\mathrm{MH}$ & $\mathrm{MH}$ \\
\hline Mali & L & L & $\mathrm{L}$ & L & L & ML & ML & ML & ML & ML & ML & ML & $\mathrm{ML}$ & ML & $\mathrm{MH}$ & $\mathrm{ML}$ & ML & $\mathrm{MH}$ & $\mathrm{MH}$ & $\mathrm{MH}$ & $\mathrm{MH}$ & $\mathrm{MH}$ \\
\hline Mauritania & ML & ML & ML & ML & ML & ML & $\mathrm{ML}$ & ML & ML & ML & $\mathrm{ML}$ & ML & $\mathrm{ML}$ & $\mathrm{ML}$ & ML & $\mathrm{ML}$ & ML & $\mathrm{MH}$ & $\mathrm{MH}$ & $\mathrm{MH}$ & $\mathrm{MH}$ & $\mathrm{MH}$ \\
\hline Mauritius & L & L & $\mathrm{L}$ & $\mathrm{L}$ & L & L & L & L & L & L & L & L & L & L & L & L & L & L & $\mathrm{L}$ & L & L & L \\
\hline Niger & L & L & L & L & L & L & L & ML & ML & ML & ML & $\mathrm{MH}$ & $\mathrm{MH}$ & $\mathrm{MH}$ & L & L & $\mathrm{MH}$ & $\mathrm{MH}$ & $\mathrm{MH}$ & $\mathrm{MH}$ & $\mathrm{MH}$ & $\mathrm{MH}$ \\
\hline Nigeria & L & L & L & L & L & L & L & L & L & ML & ML & ML & ML & ML & ML & $\mathrm{ML}$ & ML & ML & ML & ML & L & L \\
\hline Rwanda & L & L & $\mathrm{L}$ & L & L & L & L & L & L & L & L & L & L & L & L & L & L & . & $\mathrm{MH}$ & $\mathrm{MH}$ & L & $\mathrm{L}$ \\
\hline Senegal & L & L & L & $\mathrm{L}$ & L & ML & $\mathrm{ML}$ & ML & ML & ML & $\mathrm{ML}$ & $\mathrm{MH}$ & $\mathrm{MH}$ & $\mathrm{L}$ & L & L & $\mathrm{MH}$ & $\mathrm{MH}$ & $\mathrm{MH}$ & $\mathrm{MH}$ & $\mathrm{MH}$ & $\mathrm{MH}$ \\
\hline Seychelles & L & L & L & L & L & L & L & L & L & L & L & L & L & L & L & L & L & L & L & L & L & L \\
\hline Sierra Leone & $\mathrm{L}$ & L & $\mathrm{L}$ & L & L & L & L & L & L & $\mathrm{MH}$ & $\mathrm{ML}$ & L & L & $\mathrm{ML}$ & ML & $\mathrm{ML}$ & $\mathrm{MH}$ & $\mathrm{MH}$ & $\mathrm{MH}$ & $\mathrm{MH}$ & $\mathrm{MH}$ & $\mathrm{MH}$ \\
\hline Sudan & L & L & L & L & L & ML & ML & ML & ML & L & L & ML & ML & ML & ML & $\mathrm{ML}$ & ML & $M L$ & ML & ML & $\mathrm{ML}$ & $\mathrm{ML}$ \\
\hline Swaziland & L & L & L & L & L & L & L & L & L & L & L & L & L & L & L & L & L & L & L & L & L & L \\
\hline Togo & $\mathrm{L}$ & ML & ML & ML & ML & ML & ML & ML & $\mathrm{MH}$ & $\mathrm{MH}$ & $\mathrm{MH}$ & $\mathrm{MH}$ & $\mathrm{MH}$ & $\mathrm{MH}$ & $\mathrm{MH}$ & $\mathrm{MH}$ & $\mathrm{MH}$ & $\mathrm{MH}$ & $\mathrm{MH}$ & $\mathrm{MH}$ & $\mathrm{MH}$ & $\mathrm{MH}$ \\
\hline Uganda & . & . & . & L & $\mathrm{MH}$ & $\mathrm{L}$ & L & $\mathrm{L}$ & L & L & L & L & L & $\mathrm{L}$ & $\mathrm{MH}$ & $\mathrm{MH}$ & $\mathrm{MH}$ & $\mathrm{MH}$ & L & L & L & L \\
\hline Zambia & ML & ML & ML & ML & ML & ML & $\mathrm{ML}$ & ML & ML & ML & $\mathrm{MH}$ & ML & $\mathrm{MH}$ & $\mathrm{MH}$ & $\mathrm{MH}$ & $\mathrm{MH}$ & $\mathrm{MH}$ & $\mathrm{MH}$ & $\mathrm{MH}$ & $\mathrm{MH}$ & $\mathrm{MH}$ & $\mathrm{MH}$ \\
\hline Zimbabwe & L & $\mathrm{L}$ & L & L & L & L & L & L & L & L & L & L & L & L & L & L & L & L & $\mathrm{MH}$ & L & L & $\mathrm{MH}$ \\
\hline Numbe & 32 & 30 & 30 & 29 & 26 & 23 & 23 & 19 & 17 & 18 & 13 & 15 & 14 & 15 & 14 & 13 & 11 & 7 & 8 & 9 & 11 & \\
\hline Number of lov & 2 & 4 & 4 & 5 & 7 & 9 & 8 & 13 & 12 & 13 & 14 & 12 & 12 & 11 & 10 & 11 & 9 & 8 & 8 & 8 & 7 & 7 \\
\hline Number of high multilateral debt & $\overline{0}$ & 0 & 0 & 0 & 3 & 4 & 5 & 4 & 6 & 6 & 9 & 8 & 9 & 10 & 12 & 12 & 16 & 20 & 20 & 19 & 18 & 20 \\
\hline Total & 34 & 34 & 34 & 34 & 36 & 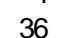 & 36 & 36 & 35 & 3 & 6 & 35 & 35 & 36 & 36 & 36 & 36 & 35 & 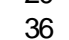 & 36 & 36 & 36 \\
\hline
\end{tabular}

Note: The three debt classification are constructed as follows: L, the low debt regime characterizes years where a country's debt to GDP ratio is below 62.8 percent; ML, the high debt, low multilateral category regime characterizes years where a country's total debt to GDP ratio is greater than 62.8 percent and the share of multilateral debt in total debt is less than 41.2 percent; and $\mathrm{MH}$, the high debt, high multilateral regime characterizes years when a country's total debt to GDP ratio is greater than 62.8 percent and the share of multilateral debt in total debt is greater than 41.2 percent.

Source: Authors' classification based on World Bank, various years, Global Development Finance.

We next use this classification to compare the behavior of net transfers across the three debt regimes. We start by plotting the average ratio of net transfers to GDP for the three debtor classes (figure 1). Net transfers as a share of GDP have been greater in almost all years for the countries in the two high debt categories, especially for those in the high multilateral debt category. Net transfers have declined over time for the countries in all regimes, somewhat more in the high multilateral debt regime and especially so in the low multilateral debt regime. 


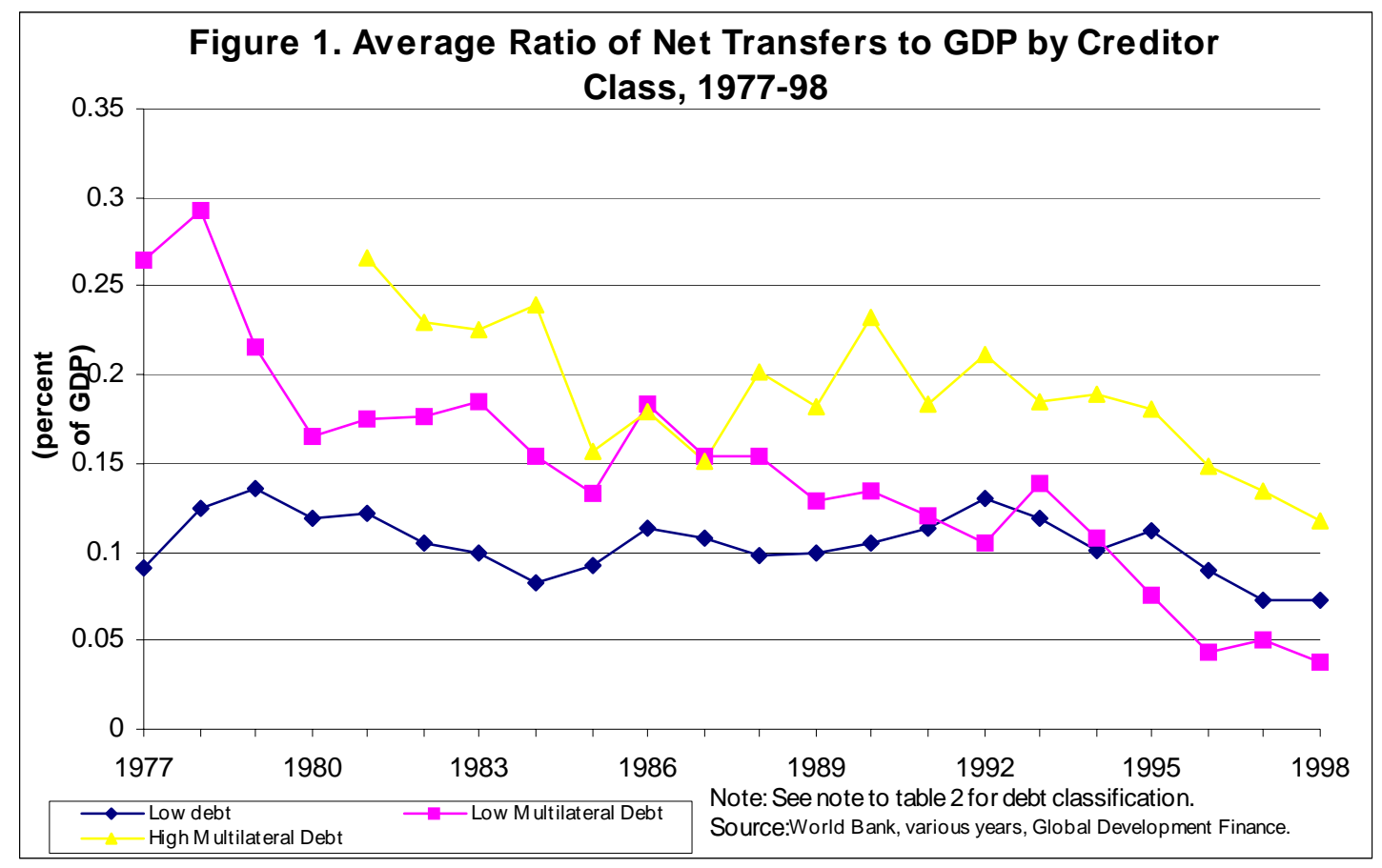

Table 3 shows the means (and standard deviations) for the net transfers variable for all countries and for the three debt regimes, averaging over all years. Consistent with figure 1, net transfers have been systematically higher for the high debt countries, especially the high multilateral cases. For the whole period high multilateral debt countries received net transfers equal to some 18 percent of GDP, compared with some 10 percent of GDP for the low debt group. The low multilateral debt cases (a subdivision of the high debt regime) received some 15 percent of GDP.

Table 3. Means and Standard Deviations for Sample Countries, 1997-98 Average

\begin{tabular}{|c|c|c|c|c|c|c|c|c|}
\hline \multirow[b]{3}{*}{ Variable } & \multirow[b]{3}{*}{ Mean } & \multirow{3}{*}{$\begin{array}{l}\text { All } \\
\text { Standard deviation }\end{array}$} & \multirow[b]{3}{*}{ Mean } & \multirow{3}{*}{$\begin{array}{l}\text { Low debt } \\
\text { Standard deviation }\end{array}$} & \multicolumn{4}{|c|}{$\underline{\text { High debt }}$} \\
\hline & & & & & \multicolumn{2}{|c|}{ Low multilateral debt } & \multicolumn{2}{|c|}{ High multilateral debt } \\
\hline & & & & & Mean & Standard deviation & Mean & Standard deviation \\
\hline Net transfers / GDP & 0.135 & 0.119 & 0.104 & 0.087 & 0.146 & 0.151 & 0.183 & 0.117 \\
\hline CPIA & 2.763 & 0.813 & 2.963 & 0.831 & 2.488 & 0.698 & 2.895 & 0.670 \\
\hline PVTDSGDP & 0.547 & 0.339 & 0.323 & 0.160 & 0.837 & 0.308 & 0.651 & 0.306 \\
\hline GDPCAP & 753 & 1,082 & 981 & 1,314 & 635 & 919 & 321 & 128 \\
\hline POP & $10,824,872$ & $16,612,134$ & $8,527,659$ & $14,559,811$ & $16,741,602$ & $23,105,792$ & $7,601,202$ & $7,240,667$ \\
\hline Number of observations & \multicolumn{2}{|r|}{848} & \multicolumn{2}{|r|}{394} & \multicolumn{2}{|r|}{239} & \multicolumn{2}{|r|}{215} \\
\hline
\end{tabular}

Note: The net transfers variable is in US dollars and is scaled by US dollar GDP. CPIA is the policy measure from the World Bank. PVTDSGDP is the present value measure of all future scheduled debt service payments relative to GDP. GDPCAPij is GDP per capita, measured in thousands of dollars. POP is population size, in logarithms. See note to table 2 for debt classifications.

Source: Authors' computations based on World Bank, various years, Global Development Finance, for debt data; IMF, various years, International Financial Statistics, for GDP per capita; and World Bank, various years, World Development Indicators, for population. 


\section{CREDitor AND DonOR SELECTIVITy: EMPIRICAL ANALYSIS}

The aggregate statistics indicate that countries that found themselves with higher debts, especially to multilateral institutions, received larger net transfers than other countries. Higher net transfers to more-indebted countries need not mean, however, that there was some kind of inefficiency. For one, some unobserved country characteristics, such as a high level of poverty or good policies, may have led donors to provide high net transfers. These high net transfers in the past may have been in the form of high lending in the past, resulting in a high debt stock. So countries highly indebted today may have been receiving more net transfers in both the past and present because they have a higher degree of poverty or better policies. We would call the higher transfers inefficient, however, if they were going to highly indebted countries independent of the quality of their domestic policy, their institutional capacity to productively absorb flows, and their poverty level. In that case, the high indebtedness, particularly to multilateral creditors, could be a barrier to selectivity in lending across countries.

\section{Policy Variables}

We therefore need to control for country characteristics in our net transfers comparisons. For policy, we use an explicit measure of the quality of the policy environment in each country in each year: the World Bank's Country Policy and Institutional Assessment (CPIA). This measure, calculated annually by World Bank country specialists, has 20 components measuring macroeconomic, sectoral, social, and public sector institutions and policies on a scale of 1 to 6 . It is determined on the basis of criteria standardized across countries. A separate World Bank unit makes a considerable effort to ensure consistency and comparability across countries and over time. ${ }^{7}$

The CPIA has been used by other researchers in investigating the determinants of aid flows, most notably Burnside and Dollar (2000) and Collier and Dollar (2002). It is considered a meaningful measure of the quality of the policy framework in a country in each year. The CPIA also has the advantage of including not only criteria related to public policy effort but also those related to institutional capacity and governance (rule of law, anti-corruption efforts). It may thus be more closely related to a country's capacity to absorb transfers effectively than traditional measures of policy effort (such as trade and financial liberalization, privatization, and inflation). ${ }^{8}$

${ }^{7}$ The ratings have an element of judgment that may be affected by specialists' separate knowledge of a country's actual or likely overall prospects. This makes the ratings potentially endogenous to, for example, growth, though probably less to net transfers in a particular year.

${ }^{8}$ In the absence of any good argument for alternative weighting of the components, we use the average. Collier and Dollar (2002) show that their results regarding aid allocation and poverty are not sensitive to reweighting the components. 
A disadvantage of the CPIA index is that it may be influenced by incentives to affect (indirectly) the lending behavior of the World Bank. Specifically, country managers may want (and be able) to improve their countries' ratings to justify a larger lending program for their country. To the extent this is true, however, the link between policy as measured by the CPIA and lending will be overstated, and any result showing that policy is not a factor will thus be a stronger result. An additional disadvantage is that the actual CPIA is available only to the public at the country level in more aggregated form, so that our results can be replicated only inside the World Bank.

We therefore use as a robustness test the policy index created by Burnside and Dollar (2000), based on publicly available information. Specifically, the index weights the following three variables: budget surplus as a share of GDP, the rate of inflation, and the degree of openness of the economy, as measured by Sachs and Warner (1995). ${ }^{9}$ This alternative policy index is a somewhat cruder measure of the quality of policy and institutional environment and we can expect results to be less strong. Nor can the policy index be created for all countries and all years because some of the component variables are not always available. Because of missing data the sample of country-year observations for the policy index is much smaller, 484 compared with 848 for the CPIA sample.

To investigate the relationship between net transfers and policy by different categories of indebtedness, we first use the CPIA index to classify countries into two groups, those with a CPIA of less than 3, so-called "bad" policy countries, and those with a CPIA equal to or greater than 3, so-called "good" policy countries. We do this for the whole group as well as separately for the three debt categories. The split for the whole group is 46 percent $/ 54$ percent-that is, about half of the country-year observations are bad policy country-years and half are good policy country-years. We then calculate the mean net transfers as a share of GDP for each subclassification. We find that there are some statistically significant differences in net transfers between bad and good policy countries (table 4, panel A).

For all countries combined, bad policy countries receive on average some 1.5 percentage points of GDP more in net transfers than good policy countries do. This difference is also statistically significant.

There are no statistically significant differences in net transfers between bad and good policy countries for the groups of low debt and low multilateral debt countries. The difference in net transfers for the overall sample seems to be caused by the behavior of net transfers to the high multilateral debt countries, where there is a difference between bad and good policy countries of 4.1 percentage points of GDP. This difference is statistically significant, with a t-statistic of 2.6. In other words, countries highly indebted to multilaterals received more net transfers when their policies were worse than average.

\footnotetext{
${ }^{9}$ The equation developed by Burnside and Dollar (2000) is: Policy $=1.28+6.85 *$ Budget Surplus $-1.40 *$ Inflation $+2.16 *$ Openness.
} 
When we use the sample for the alternative policy index, we find similar effects for the debt breakdowns, but different effects for the further breakdown by the policy index (table 4, panel B). The comparisons in net transfers between the debt groups are qualitatively similar to the overall comparisons: the low debt group receives net transfers equal to 8.4 percentage points of GDP and the low multilateral debt group 9 percentage points, while the high multilateral debt group receives 15.7 percentage points, a difference of 7 percentage points over the low debt group.

The breakdown between good and bad policy countries does not indicate the same results. For the high multilateral debt group, bad policy countries actually receive some 2.5 percentage points less in net transfers. For none of the debt classifications, however, is there a statistically significant difference between the bad and good policy countries, possibly because the sample is smaller and the index cruder, or because we have not yet controlled for other variables.

Table 4. T-test on Net Transfers/GDP

Panel A Based on CPIA

\begin{tabular}{|c|c|c|c|c|c|c|c|c|}
\hline CPIA & All & Difference t-test & Low debt & $\begin{array}{c}\text { Difference } \\
\text { t-test }\end{array}$ & $\begin{array}{c}\text { Low } \\
\text { multilateral } \\
\text { debt }\end{array}$ & t-test & $\begin{array}{c}\text { High } \\
\text { multilateral } \\
\text { debt }\end{array}$ & $\begin{array}{c}\text { Difference } \\
\text { t-test }\end{array}$ \\
\hline All & 0.135 & & 0.103 & & 0.146 & & 0.183 & \\
\hline Good & 0.127 & 0.015 & 0.103 & 0.001 & 0.145 & 0.001 & 0.163 & 0.041 \\
\hline $\mathrm{Bad}$ & 0.142 & 1.810 & 0.103 & -0.110 & 0.147 & -0.220 & 0.204 & 2.610 \\
\hline
\end{tabular}

\begin{tabular}{|c|c|c|c|c|c|c|c|c|}
\hline anel B & Based on Alte & Variable & & & & & & \\
\hline Policy & All & $\begin{array}{c}\text { Difference } \\
\text { t-test }\end{array}$ & Low debt & $\begin{array}{c}\text { Difference } \\
\text { t-test }\end{array}$ & $\begin{array}{l}\text { Low } \\
\text { multilateral } \\
\text { debt }\end{array}$ & $\begin{array}{c}\text { Difference } \\
\text { t-test }\end{array}$ & $\begin{array}{c}\text { High } \\
\text { multilateral } \\
\text { debt }\end{array}$ & $\begin{array}{c}\text { Difference } \\
\text { t-test }\end{array}$ \\
\hline All & 0.103 & & 0.084 & & 0.090 & & 0.157 & \\
\hline Good & 0.103 & 0.000 & 0.080 & 0.008 & 0.079 & 0.016 & 0.168 & -0.025 \\
\hline $\mathrm{Bad}$ & 0.103 & -0.051 & 0.088 & 0.868 & 0.095 & 0.803 & 0.143 & -1.384 \\
\hline
\end{tabular}

Note: The t-test measures the statistical significance of the difference in net transfers between the good and bad policy countries. The net transfers variable is in US dollars and is scaled by US dollar GDP. CPIA is the policy measure from the World Bank. See note to table 2 for debt classification.

Source: Authors' computations based on World Bank, various years, Global Development Finance.

\section{Other Country Characteristics}

So far, the analysis has investigated only the simple interrelationships between the quality of policy, indebtedness, and net transfers. The raw statistics suggest that the degree and nature of indebtedness affect the relationship between policy and net transfers under the CPIA, although not under the alternative index. But the data remain suggestive because they do not yet control for other country characteristics and they vary by policy index and sample. The data in table 3 already indicate that it can be important to control for other country characteristics because there are large differences in GDP per capita and population size between the three groups of indebtedness countries. To properly assess the relationship between net transfers and the quality of policy, we therefore extend our 
analysis by performing a multivariate regression, controlling for several country characteristics.

The first control variable is the degree of indebtedness. Since the stock of debt is simply a transformation of accumulated past borrowing, it could be that high debt reflects country circumstances or policies can explain large net transfers in the past. These characteristics could include former colonial ties (Alesina and Dollar 2000), strategic interests of donors, openness of the economy, policy stance, or other country factors. These country characteristics may lead countries that received high net transfers in the past, and thus have high debt stocks, to continue to receive net transfers today. Including past indebtedness will control for some of this tendency.

Second we want to control for the degree of poverty in the country because donors may provide net transfers in relation to a country's degree of poverty irrespective of policy indebtedness and other country factors. Controlling for the incidence of poverty is difficult, however, because poverty data are not available for long time periods. We have only a small, cross-country sample of poverty data for the 1990s. We therefore use instead GDP per capita (in dollars) as a proxy for the incidence of poverty (as well as the overall level of development of the country). The high multilateral debt countries are much poorer on average than the low debt countries, \$320 per capita versus \$980 per capita (see table 3). Perhaps they receive more net transfers simply because they are poor, and the relationship between net transfers and indebtedness arises because of greater poverty levels in high debt countries.

Third we want to control for the size of economy since there is a tendency for smaller countries to receive relatively more aid, as reported among others by Burnside and Dollar (2000). (This relationship may arise because small countries tend to be more open and thus more exposed to international shocks, because donors expect greater influence on policy in smaller countries, or for other reasons.) In our specification, we use the logarithm of population as a control variable for size.

To control for any other country differences and possible endogeneity in the relationships, we use a fixed effects estimation technique. Fixed effects allow us to control for any unobserved country characteristics and to take care of any (remaining) endogeneity issues. We also employ ordinary least squares as a test of robustness. We estimate the following model:

(2) $N T_{i j}=\alpha+\beta_{1} * P V T D S G D P_{i j}+\beta_{2} * G D P C A P_{i j}+\beta_{3} * L N P O P_{i j}+\beta_{4} * C P I A_{i j}+\beta_{5} *(D e b t$ classification interacted with policy dummies ${ }_{1,2,3}$ for country $i$ and year $\left.j\right)$.

The net transfers variable for country $i$ in year $j, N T_{i j}$, is scaled to GDP. PVTDSGDP $_{\mathrm{ij}}$ is the present value measure of all future scheduled debt service payments relative to GDP, which thus takes into account the concessionality of debt. This measure is preferred to such measures as the total debt stock to GDP, which ignores the concessionality of debt, or the ratio of annual debt service to GDP, which does not provide a measure of the full future debt burden. PVTDSGDP is taken from the Global 
Development Finance database. GDP per capita in thousands of dollars, GDPCAP, is used as a proxy for the overall level of development of the country and the incidence of poverty. Data on GDP per capita are from the IMF International Financial Statistics. Population size in logarithms, LNPOP, is to control for the size of the country and comes from the World Bank. CPIA is our policy measure variable already introduced (which we also substitute by the alternative policy index). The three debt dummy variables interacted with good and bad policy dummy variables are constructed consistent with tables 2 and 4: for all three debt groups (low debt; high debt, low multilateral; and high debt, high multilateral) we created a separate bad policy dummy variable if the CPIA for that country-year observation was less than three (or if the alternative policy index was less than its median).

\section{Regression Results}

The regression results show that net transfers are positively related to debt stocks, consistent with figure 1 and the raw statistics of average net transfers by country indebtedness classification of table 3 (table 5). This relationship may reflect the defensive lending of donors, with high debt stocks triggering more net transfers to prevent arrears. But to prevent arrears it would be necessary only to "roll over" debt service due by providing an equal amount of new disbursements - that is, keep net transfers at zero. It would not be necessary to provide additional net transfers as debt burdens become larger.

The positive coefficient is also possible because some country characteristics not included in the regression may be correlated with past and current net transfers. But the fixed effects regression technique should control for most of these characteristics. The positive relationship is not likely to be due to the fact that the net transfers figures we use are not corrected for any official debt reduction included by donors in the grant figures they report to the OECD, for that would lead to a downward bias. ${ }^{10}$ Our preferred interpretation for the positive coefficient is that when debt stocks are large, countries manage to "bargain" for larger net transfers, perhaps because donors are more eager to prevent arrears or defaults that would increase the visibility of any failures in past lending programs.

${ }^{10}$ Correcting the net transfers for debt reduction is difficult. Renard and Cassimon (2001) write, "We have no strong basis to suggest a percentage by which the DAC figures must be reduced to give a correct expression of the costs of debt reduction to the donors." Still, as also noted by Renard and Cassimon, the inclusion of official debt reduction in aid would bias upward the net transfers countries actually received. At the same time, the total debt reduction figure is reported in Global Development Finance and the debt stock is reduced by the official debt reduction. This would upward bias net transfers and downward bias PVTDSGDP, which would mean that the coefficient on PVTDSGDP would be biased downward, weakening the relationship. Besides biasing the coefficient on the debt stocks, there could be some other bias in our regression results as well. We therefore investigated whether the estimated relationship between net transfers and policy is affected in a systematic way by degree of debt reduction. Regression results (not reported) show that all estimated coefficients are robust to the inclusion of the Global Development Finance-reported debt reduction figures as another independent variable. 
We also find that countries tend to receive larger net transfers when they are poor-the coefficient on GDP per capita is statistically significant and negative. ${ }^{11}$ There is also evidence of a small-country effect - the coefficient for population (in logs) is statistically significant and negative.

Table 5. Basic Result for Net Transfers Regression

\begin{tabular}{|l|c|c|c|}
\hline \multirow{2}{*}{\multicolumn{2}{|c|}{ CPIA }} & Alternative policy \\
Variable & \multicolumn{2}{|c|}{} \\
\cline { 2 - 3 } \multicolumn{1}{c|}{} & \multicolumn{2}{|c|}{ Ordiable } \\
\hline PVTDSGDP & Fixed effect & $0.101(9.47)$ & $0.107(6.23)$ \\
GDPCAP & $0.097(8.26)$ & $-0.058(-17.26)$ & $-0.011(-1.75)$ \\
INPOP & $-0.022(-4.10)$ & $-0.041(-17.12)$ & $-0.091(-4.95)$ \\
CPIA or policy & $-0.114(-7.97)$ & $0.004(0.60)$ & $0.000(0.04)$ \\
BPL & $0.003(0.63)$ & $0.012(1.13)$ & $-0.004(-0.56)$ \\
BPLM & $0.000(0.00)$ & $-0.001(-0.09)$ & $-0.008(-0.76)$ \\
BPHM & $0.009(1.01)$ & $0.030(2.54)$ & $0.017(1.77)$ \\
Constant & $0.026(2.86)$ & $0.735(16.33)$ & $1.480(5.21)$ \\
\hline
\end{tabular}

\begin{tabular}{|l|r|r|r}
\hline Number of observations & 848 & 848 & 484 \\
F-value & 22.53 & 89.44 & 11.52 \\
R-squared (adjusted) & & 0.422 & \\
Within & 0.17 & & 0.155 \\
Between & 0.28 & & 0.156 \\
Overall & 0.17 & & 0.046 \\
\hline
\end{tabular}

Note: Numbers in parentheses are t-statistics. The net transfer variable is in US dollars and is scaled by US dollar GDP. PVTDSGDP is the present value measure of all future scheduled debt service payments relative to GDP. GDPCAP is GDP per capita, measured in thousands of dollars. The coefficients for GDPCAP are multiplied by 1,000. LNPOP is population size, in logarithms. CPIA is the policy measure from the World Bank. Policy is the alternative policy variable. See note to table 2 for debt classifications.

Source: Authors' computations based on World Bank, various years, Global Development Finance, for debt data; IMF, various years, International Financial Statistics, for GDP per capita; and World Bank, various years, World Development Indicators, for population.

Surprisingly, we find no direct effects of the policy variable on net transfers- the coefficient for the CPIA is statistically insignificant. ${ }^{12}$ It seems as if the quality of a country's policy does not affect the relative amount of net transfers it receives. When we analyze the effects of bad policy for the three debt groups, however, we find that the high

${ }^{11}$ We multiply the coefficients on GDPCAP by 1,000 for presentational purposes. As noted, poverty data are not available for long time periods, but we do have a small, cross-country sample of poverty data. When substituting poverty for GDPCAP for that sample, we find that countries with relatively greater poverty counts have larger net transfers.

${ }^{12}$ While this appears to contradict other findings, this insignificance of the policy variable mainly results from the fact that we do not use the nonlinear specification others have used. Collier and Dollar (2002) show that transfers (to all recipient countries) are nonmonotonic with respect to the CPIA; they rise for low and moderate levels of CPIA and then decline as CPIA improves. When we also allow for this nonlinearity, we find that about half of the countries lie on the upward sloping and another half on the downward sloping part of the curve. This means one cannot make a general statement on the effects of policy on net transfers. 
multilateral debt countries with bad policy receive about 2.5 percentage points more in net transfers as a share of GDP. For the other two groups, the coefficient for the bad policy dummy variables is not statistically significant. The 2.5 percentage points more in net transfers is less than the 4 percentage points reported earlier (table 4). Since the earlier comparisons did not control for country characteristics, some of the control variables partly may explain the higher net transfers.

The large remaining difference, equal to about one-fifth of the average net transfers all countries received over this period, nevertheless implies that in the high multilateral debt countries, bad policy is associated with more, not fewer net transfers. This result confirms our hypothesis that for countries highly indebted to the multilaterals, donors have not been able to practice selectivity for the policies countries have adopted (or for their institutional capability). Indeed, they have provided more, not fewer resources where policies have been worse. Our interpretation: because of the large multilateral debts, donors have allowed poor policy to continue in these countries and actually provided more resources to accommodate the larger macro-imbalances, which in turn caused the higher debt stocks.

\section{Robustness Tests}

We confirm this result using a number of robustness tests. We start by reporting the ordinary least squares (OLS) regression results (table 5). The regression results have the same signs, but somewhat different statistical significance for the various control variables. The OLS results are generally stronger for the country control variables-no surprise, since the fixed effects results control more for country differences. Again, the present value of debt to GDP has a positive statistically significant coefficient, and the level of GDP per capita and the population size (in logs) has a statistically significant negative coefficient. The policy variable, CPIA, again is not statistically significant, suggesting that the fixed effects estimator does not hide permanent characteristics related to the quality of county policy. The bad policy dummy variable again remains statistically significant, only for the high multilateral debt group, and implying a 3 percent point difference in net transfers. Our finding is thus robust to the estimation technique used.

We next investigate whether using the alternative policy index changes our results. We do so again using the fixed effects regression techniques (see table 5). We find weaker statistical significance, possibly because the sample is reduced by half, from 884 country-year observations to 484 . The coefficient on the dummy variable for the countries highly indebted to multilaterals with bad policy now indicates that these countries receive some 1.7 percentage points more in net transfers, still statistically significant at the 10 percent level. All other policy dummy variables and the policy variable itself are not significant while the control variables retain their sign and significance. This result suggests that the use of a cruder policy index does not qualitatively change our main result.

As another robustness test, we investigate whether the relationship between debt and net transfers may have been affected by the occurrence of shocks and the role of 
arrears. Many countries in the sample have faced large terms of trade shocks, frequently cited as one of the reasons for the poor economic performance, the need for continuing aid flows, and the poor policy records. If GDP were to decline systematically because of these shocks, this would not be a problem in our regressions.

But there could be a bias in our regression results if there is a relationship between shocks and the debt buildup. The argument would be as follows: Say that a country faces a surprise drop in GDP and cannot pay its debt service due. The debt to GDP ratio will rise because of the drop in GDP and the rise in debt (as arrears are capitalized into the debt stock). The net transfers to GDP ratio will also be high because GDP is low and net transfers are possibly high due to arrears that reduce debt service paid and increases in new disbursements by creditors and donors to mitigate the impact of the shock. Since there have been quite big shocks to GDP for many of the countries in our sample, this pattern of net transfers to GDP being higher for countries and years when debt to GDP is also high could bias our coefficients.

There could also be a bias through the policy response, at least as measured. If countries adjust poorly to shocks and end up with larger fiscal deficits and higher inflation, policy (as measured) could be worse when net transfers are higher. This is possible particularly for the alternative policy index, which relies heavily on the budget surplus and inflation for its construction. Furthermore, donors may be more willing to accommodate poor policies when countries face adverse shocks, creating a similar bias.

To check for this possibility, we estimated a trend measure of annual GDP by running for each country a simple regression of actual GDP on a time trend. ${ }^{13}$ We then replaced actual GDP in the various ratios (NT to GDP, PVTDS to GDP, and GDP per capita) by trend GDP as predicted by this regression. This way, the ratios are not affected by any short-run shocks to GDP. To investigate whether net transfers respond to shortrun shocks to GDP, possibly confounding the results on the policy and other variables, we also included the deviation of GDP from trend as an additional independent variable in the regression. Column 1 of table 6 reports the results, using again the fixed effects regression technique.

\footnotetext{
${ }^{13}$ We like to thank the editor for suggesting this methodology.
} 
Table 6. Regression Net Transfers on Fitted GDP and of Gross Flows on Actual G[

\begin{tabular}{|l|c|c|c|}
\hline \multicolumn{1}{|c|}{ Variable } & Net transfers & \multicolumn{2}{c|}{ Gross flows } \\
\hline PVTDSGDP & Fixed effect & Fixed effect & Ordinary least squares \\
\hline GDPCAP & $0.134(14.68)$ & $0.196(16.41)$ & $0.187(19.31)$ \\
INPOP & $-0.039(-6.55)$ & $-0.015(-2.71)$ & $-0.052(-17.01)$ \\
Residual & $-0.135(-9.67)$ & $-0.123(-8.4)$ & $-0.037(-17.11)$ \\
CPIA & $0.000(1.26)$ & NA NA & NA NA \\
BPL & $0.009(1.86)$ & $0.006(1.23)$ & $0.010(1.75)$ \\
BPLM & $0.003(0.36)$ & $0.003(0.38)$ & $0.012(1.22)$ \\
BPHM & $0.012(1.43)$ & $-0.003(-0.34)$ & $-0.016(-1.5)$ \\
Constant & $0.021(2.33)$ & $0.015(1.59)$ & $0.015(1.38)$ \\
& $2.125(9.98)$ & $1.939(8.76)$ & $0.655(16.11)$ \\
\hline Number of observations & 848 & & 848 \\
F-value & 51.55 & 50.22 & 141.96 \\
R-squared (adjusted) & & & 0.538 \\
Within & 0.342 & 0.307 & \\
Between & 0.341 & 0.337 & \\
Overall & 0.238 & 0.224 & \\
\hline
\end{tabular}

Notes: Numbers in parentheses are t-statistics. The net transfers variable is in US dollars and is scaled by US dollar GDP. GF, gross flows, is new disbursements and grant in US dollars and is scaled by US dollar GDP. PVTDSGDP is the present value measure of all future scheduled debt service payments relative to GDP. GDPCAP is GDP per capita, measured in thousands of dollars. The coefficients for GDPCAP are multiplied by 1,000 . LNPOP is population size, in logarithms. CPIA is the policy measure from the World Bank. See note to table 2 for debt classifications.

Source: Authors' computations based on World Bank, various years, Global Development Finance, for debt data; IMF, various years, International Financial Statistics, for GDP per capita; and World Bank, various years, World Development Indicators, for population.

We find that using the permanent level of GDP in the ratios and adding the departure from trend in each year does not change our main result. The coefficient on the bad policy dummy variable for the countries highly indebted to multilaterals indicates that these countries receive some 2.1 percentage points more in net transfers, statistically significant at the 5 percent level. The coefficients on the control variables PVTDSGDP, GDPCAP, and LNPOP do not change much in magnitude and actually become somewhat more significant. Interestingly, the deviation from trend GDP, while positive, is not statistically significant. This suggests that net transfers are not being adjusted much in response to short-run shocks to GDP. And even if they are, this pattern does not affect the overall relationship that we stress - high indebtedness and poor policy lead to larger net transfers. In other words, donors do not necessarily adjust net transfers in response to shocks, but they are more willing to accommodate poor policy when multilateral debts are large. In that sense, our conclusions are reinforced.

We further confirm the importance of debt stocks in determining donor behavior by investigating the behavior of gross flows, instead of net transfers. We can rewrite the left-hand side variable of equation 1 as $N T=G+N B-D S$, with net transfers being new grants plus debt disbursements minus debt service. Taking into account that debt service 
is necessarily strongly related to the outstanding stock of debt, it is likely that gross flows, $N B+G$, are much more sensitive to debt stocks than net transfers are. To check for the role of debt stocks in gross flows, we replace in the base regression the dependent variable net transfers by the variable gross flows, also scaled by GDP, and rerun the regression. Columns 2 and 3 of table 6 report these results, using fixed effects and OLS regression techniques.

As expected, debt stocks, PVTDSGDP, are a very important determinant of gross flows, with a coefficient on debt stocks of 0.2 , compared with 0.1 in the base regression for net transfers. This confirms that creditors and donors provide gross flows in response to debt service due - that is, they roll over gross claims, which itself is closely related to debt stocks. But there is an additional effect related to debt classification and policy that adds to this tendency to provide gross flows. While the coefficient on the bad policy dummy is less significant, it still indicates that gross flows are 1.5 percentage points higher to countries with poor policies highly indebted to multilaterals. Again, the results suggest that donors respond perversely to debt stocks, disbursing regardless of policy and other country circumstances, and providing more to countries with poor policies highly indebted to multilaterals.

Finally, we show the perverse relationships between net transfers and policy in the countries highly indebted to multilaterals by plotting the simple, univariate scatter of net transfers and the CPIA for each of the three indebtedness groups (figure 2; the results of simple univariate regressions are also reported). As can be seen, only for the countries highly indebted to multilaterals is there a negative relationship between net transfers and the CPIA. For the other indebtedness groups, the relationship is nonexistent.

Figure 2 Net Transfers and Policy by Debtor Classification

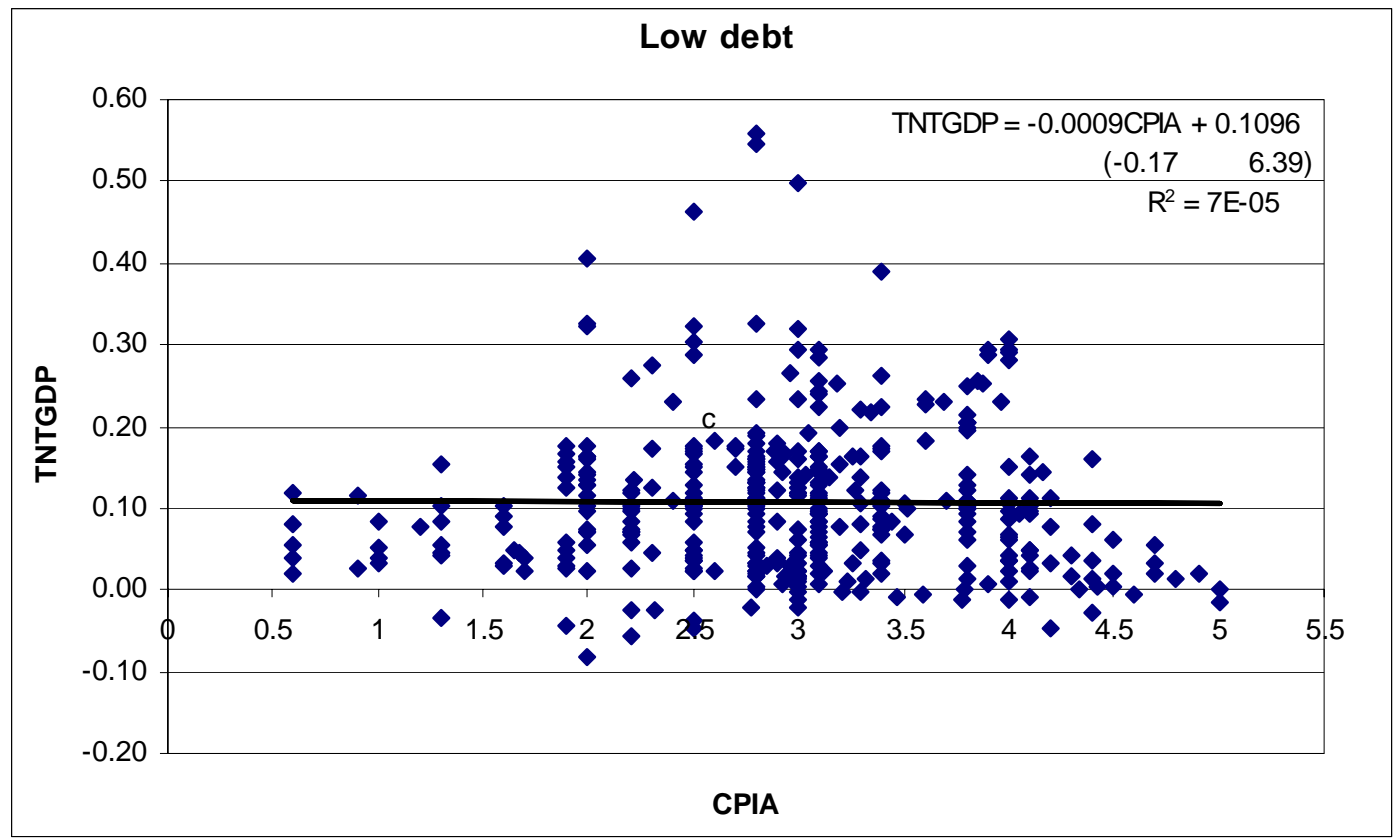



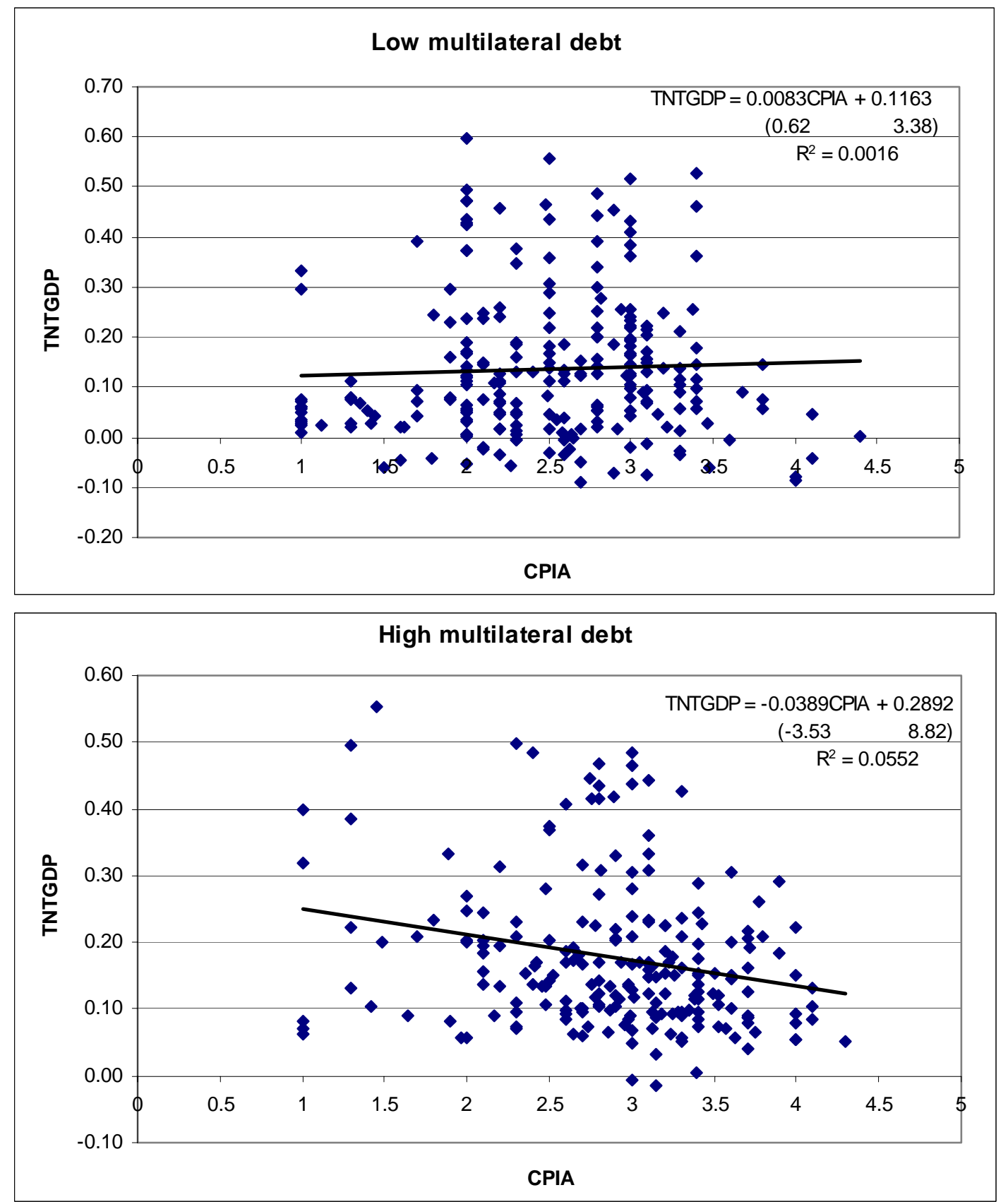

Note: See note to table 2 for debt classification.

Source: Authors' computations based on World Bank, various years, Global Development Finance.

We also address the question whether some donors and creditors are more sensitive to debt stocks and more selective for policy than others are. We do so by distinguishing among net transfers of five classes of donors or creditors:

- The International Development Association (IDA) (concessional) and International Bank for Reconstruction and Development (IBRD) windows of the World Bank.

- The IMF. 
- All multilaterals combined (IDA, IBRD, and IMF, as well as such other multilaterals as the African Development Bank and European Investment Bank).

- All bilaterals combined (including grants as well as loans).

- Private creditors (only the net transfers they provide to the governments are included).

Table 7 shows the results, using the same regression specification as in table 5 and employing the fixed effects estimator, but running separate regressions for each class of

\begin{tabular}{|c|c|c|c|c|c|c|}
\hline Variable & IDA & IBRD & IMF & All multilateral & Bilateral plus grant & Memo: Private \\
\hline PVTDSGDP & $0.027(12.83)$ & $-0.003(-2.38)$ & $-0.008(-3.12)$ & $0.025 \quad(5.99)$ & $0.085(9.30)$ & $-0.013(-2.57)$ \\
\hline GDPCAP & $0.000(0.10)$ & $-0.001(-1.29)$ & $-0.001(-0.98)$ & $-0.003 \quad(-1.66)$ & $-0.020(-4.71)$ & $0.001(0.57)$ \\
\hline INPOP & $0.010(3.85)$ & $-0.013(-7.81)$ & $-0.013(-4.22)$ & $-0.033 \quad(-6.42)$ & $-0.048(-4.26)$ & $-0.034(-5.67)$ \\
\hline CPIA & $0.002(2.54)$ & $0.001(1.30)$ & $0.003(2.46)$ & $0.006 \quad(3.59)$ & $-0.003(-0.89)$ & $0.000(0.12)$ \\
\hline BPL & $-0.001(-0.62)$ & $-0.001(-1.40)$ & $0.001(0.54)$ & $-0.001 \quad(-0.18)$ & $0.002(0.35)$ & $-0.002(-0.50)$ \\
\hline BPLM & $-0.004(-2.38)$ & $0.000(-0.51)$ & $0.003(1.51)$ & $0.003 \quad(1.08)$ & $0.005(0.72)$ & $0.001(0.15)$ \\
\hline BPHM & $-0.001(-0.50)$ & $0.001(0.74)$ & $0.003(1.64)$ & $0.003 \quad(0.99)$ & $0.021(3.07)$ & $0.001(0.29)$ \\
\hline Constant & $-0.156(-4.05)$ & $0.191(7.85)$ & $0.200(4.21)$ & $0.491 \quad(6.36)$ & $0.812(4.80)$ & $0.531(5.79$ \\
\hline Number of observations & 848 & 848 & 848 & 848 & 848 & 848 \\
\hline F-value & 45.93 & 14.62 & 7.12 & \multirow[t]{2}{*}{13.95} & 23.53 & 8.98 \\
\hline R-squared (adjusted) & & & & & & \\
\hline Within & 0.29 & 0.11 & 0.06 & 0.11 & 0.17 & 0.07 \\
\hline Between & 0.00 & 0.09 & 0.00 & 0.21 & 0.34 & 0.07 \\
\hline Overall & 0.07 & 0.02 & 0.00 & 0.05 & 0.27 & 0.01 \\
\hline
\end{tabular}

Note: Numbers in parentheses are t-statistics. The net transfer variable is in US dollars and is scaled by US dollar GDP. PVTDSGDP is the present value measure of all future scheduled debt service payments relative to GDP. GDPCAP is GDP per capita, measured in thousands of dollars. The coefficients for GDPCAP are multiplied by 1,000. LNPOP is population size, in logarithms. CPIA is the policy measure from the World Bank. Policy is the alternative policy variable. See note to table 2 for debt classifications. Source: Authors' computations based on World Bank, various years, Global Development Finance, for debt data; IMF, various years, International Financial Statistics, for GDP per capita; and World Bank, various years, World Development Indicators, for population.

creditor.

For the net transfers from the IDA window and the bilaterals, the coefficients for the debt stock (PVTDSGDP) variable are statistically significant and positive, suggesting an element of defensive lending and bargaining by the country. (Again, the effects of lagged net transfers, due to some unknown or unmeasured country characteristic leading to both high debt stocks and high current transfers, is less likely because we used fixed effects.)

For the IBRD and IMF, however, the coefficients for the debt stock variable are statistically significant and negative, suggesting their greater concern with creditworthiness, thus cutting back new lending to more indebted countries. This is similar to the negative coefficient for the net transfers behavior of the private sector, which can safely be assumed to be mostly concerned with getting repaid.

For all multilaterals combined, the sign for the debt stock variable is statistically significant and positive, suggesting that IDA and the other multilaterals compensate for the repayment-oriented behavior of the net transfers for the IMF and the IBRD.

Combined, these donors are mainly involved in defensive lending, or they relate their net transfers to some other country characteristic not controlled for yet. The coefficients for the control variables, GDPCAP and LNPOP, are generally the same as for the overall net 
transfers regressions, although not always statistically significant. The exception appears to be IDA, where there is a large-country effect, rather than a small-country effect.

The coefficients on the policy variable CPIA are statistically insignificant for the net transfers from the IBRD and bilaterals, as well as for the net transfers from the private sector. Net transfers from IDA and the IMF, and all multilaterals combined, relate in a positive way to the quality of policy, with the coefficients also statistically significant. The positive relationship for IDA can be expected because the allocation of IDA resources is explicitly linked to the quality of the policy framework. For the bilaterals, in contrast, high indebtedness to multilaterals when combined with bad policy has perverse effects. The bad policy effect for the high multilateral debt category for the bilaterals is large, some 2.1 percentage points of GDP. For the IMF, there is also a positive effect on net transfers from belonging to the bad policy, high multilateral debt countries, but it is only 0.3 percentage points, significant only at the 10 percent level.

The IDA and the IBRD, as well as all multilaterals combined, have no significant bad policy effect, and IDA actually provides fewer net transfers to bad policy countries with high debt but a low share of multilateral debt. Since the bilaterals increase net transfers to GDP for the bad policy and high multilateral debt countries by some 2.1 percentage points, close to the total 2.5 percentage points effect for all net transfers (as reported in table 4), it seems that the higher net transfers going to bad policy countries is almost entirely due to the bilateral donors. ${ }^{14}$ Although we found the quantitative effects of the IMF to be small, the IMF is very important-because in the Paris Club reschedulings and donor meetings, an IMF program is almost always required. Seemingly, the IMF provides the signal of accommodating bad policy more easily for countries that have high debts to the multilaterals.

As a last robustness test, we ran separately for each class of indebtedness the base regression, but without the policy-debt interaction dummy variables, to investigate the behavior of each creditor or donor with respect to policy for each type of country (not reported). The sample sizes vary (394 for the low debt group, 239 for the high debt, low multilateral group, and 215 for the high debt, high multilateral group). We find net

${ }^{14}$ We also conducted OLS regression, with results essentially the same overall as the net transfers regression. When using our alternative policy index, we find that policy is no longer significant for any creditor or donor class. Bilaterals and IMF still transfer some 1.3 and 0.4 percentage points respectively more to bad policy, high multilateral debt countries, while IDA transfers less to bad policy countries in all three indebtedness classes, and IBRD transfers somewhat less to the bad policy, high multilateral debt countries. When using the trend GDP to calculate the ratios and adding the deviation from trend GDP as another regression variable, we find that the bilaterals transfer 1.9 percentage points more to the bad policy, high multilateral debt countries while IDA transfers less to bad policy countries in the high debt, low multilateral indebtedness class. We also find some evidence of smoothing of income shocks for net transfers from IDA and IMF as the coefficients on the residual GDP are positive for these two classes. Policy remains insignificant for all classes, however, except for net transfers from private creditors, where it is positive. Finally, regression results for gross flows (instead of net transfers) as dependent variable show that the coefficient for the debt stocks is the highest for the bilaterals and that the bilaterals provide 1.7 percentage points more in gross flows to the bad policy, high multilateral debt countries. IDA gross flows are less to bad policy, low multilateral debt countries, but respond positively to policy, as do IMF gross flows. All these results are not reported, but are available from the authors. 
transfers from IDA to be significant positively related to policy for the low debt and the high multilateral debt group (though only at the 10 percent level for the latter). For the net transfers from the IMF, the policy variable is statistically significant and positive only for the low multilateral debt group, while for the bilaterals the policy variable is actually statistically significant negative for the low multilateral debt group. For all multilaterals combined, the policy variable is positive and significant for the low debt and the low multilateral debt groups, but not for the high multilateral debt group. This confirms again that donors have more difficulty being selective about policy for the high multilateral debt countries, actually acting perversely, but in low debt countries they have been able to be selective.

\section{CONCLUSIONS AND IMPLICATIONS}

Net transfers remained positive over two decades in most Sub-Saharan countries, falling only somewhat in the 1990s. But with low growth in recipient countries, continuing net transfers meant a rising stock of debt relative to output. The bilateral donors tried to minimize the resulting burden of debt service by shifting to grants and offering repeated rounds of debt service relief. ${ }^{15}$ The multilateral institutions were more restricted in ensuring repayments to themselves with new loans, since these loans would only increase the debt burden. At the same time, the multilaterals could not accept arrears. Bilateral donors in effect were ensuring that some of the poorest countries would not, despite poor policies, be pushed into arrears to the multilaterals.

Countries "benefited" from this need to avoid arrears since they could bargain for more net transfers as their debt stocks increased. The core reason was that arrears to the multilaterals are a problem for all donors since they signal the end of "business as usual" for the other donors as well-and would be seen as a failure of the development assistance business in that country. Importantly, this need to maintain net transfers came at the cost of losing selectivity for country policy, especially for countries with bad policy highly indebted to multilaterals. For these countries, the development community actually accommodated poor policies through higher net transfers.

This interpretation has important policy implications. It suggests that if debt levels are reduced enough in countries with high multilateral debt, the behavior of the donor community can then shift into a low debt regime for those countries - a regime that in the past has allowed selectivity for multilaterals, at least for IDA. Debt service reduction under HIPC (now enhanced under HIPC II) can thus be interpreted as a way "out" for a donor community otherwise locked into nonselectivity in the high multilateral debt countries. $^{16}$

${ }^{15}$ As some countries' GDP per capita fell (Côte d'Ivoire, Nigeria), some countries became eligible for cheaper IDA loans from the World Bank and concessional loans from the African Development Bank. That also helped minimize the burden of increasing debt service.

${ }^{16}$ Debt relief under the HIPC Initiative is unlikely to directly free resources in high debt countries for spending on the poor. It has not been high debt burdens that have constrained resources transfers. High 
Debt relief, by encouraging selectivity and changing donor behavior for the better, can ensure more funds for countries currently indebted but with good policies. As others have shown, providing additional resources to countries with good policies would help enhance their growth and lead to more poverty reduction. Without additional donor resources, selectivity would imply fewer funds for countries with bad policies. ${ }^{17}$ Ironically, the return to more selective transfers may avoid the full costs of the debt reduction program. That would be the case if the HIPC Initiative is "paid for" out of traditional donor financing, leading to lower future transfers to HIPC or other poor countries. The fact that some of the "grant" figures today already include an official debt reduction suggests that donors see grants and debt reduction to some extent as substitutes.

Though necessary, debt reduction is far from sufficient to ensure donor selectivity. There is a need, particularly following what may become "nonselective" debt relief, for greater emphasis on selectivity in future grant-making and lending. This will require deep institutional changes on the part of the donors, in their bilateral programs and in their influence on the multilaterals. Fortunately, our analysis of the past behavior of creditors suggests that with debt reduction, this is at least possible. Donors can make the necessary break with past practice - and thus increase their contribution to the tremendous development challenges in Africa. Better donor behavior would also set the stage for more effective development assistance in the long run, and making it politically possible to convince the public in donor countries to maintain and even raise development assistance budgets.

debt countries have been receiving more net transfers relative to other poor countries. Debt reduction alone does not free up resources for countries if debt is not being effectively serviced to begin with. But it is likely that in some countries transfers in the form of multiple donor projects, often tied to donor supplied services, were not a good substitute for the direct increase in revenues (through a decrease in tax-financed debt service) that debt relief provides. Birdsall and Williamson (2002) argue that in well-managed countries, debt relief is more efficient as a form of aid than donor-financed projects.

17 The latter group could end up with reduced net transfers simply because the debt reduction will make it easier for donors and creditors to reduce what our evidence suggests is now forced defensive lending. Debt reduction can also more effectively create a virtuous circle by crowding in private flows to good policy/low debt countries (Birdsall and Williamson 2002). See also Berlage et al. (2003). 


\section{References}

Alesina, Alberto, and David Dollar. 2000. "Who Gives Foreign Aid to Whom and Why?" Journal of Economic Growth 5(1): 33-63.

Berlage, Lodewijk, Danny Cassimon, Jacques Dreze and Paul Reding. 2003. "Prospective Aid and Indebtedness Relief: A Proposal.” World Development 31(10): 1635-54.

Birdsall, Nancy, and Johan Williamson, with Brain Deese. 2002. Delivering on Debt Relief: From IMF Gold to a New Aid Architecture. Washington, D.C.: Center for Global Development and Institute for International Economics.

Burnside, Craig, and David Dollar. 2000. “Aid, Policies, and Growth.” American Economic Review 90(4): 847-68.

Claessens, Stijn, and Ishac Diwan. 1994. "Recent Experience with Commercial Debt Reduction: Has the "Menu” Outdone the Market?” World Development 22(2): 20113.

Claessens, Stijn, Enrica Detragiache, Ravi Kanbur, and Peter Wickham. 1997. "HeavilyIndebted Poor Countries’ Debt: Review of the Issues.” Journal of African Economies 6(2): 231-54.

Collier, Paul, and David Dollar. 2002. “Aid Allocation and Poverty Reduction.” European Economic Review 46(9): 1475-1500.

Diwan, Ishac, and Dani Rodrik. 1992. External Debt, Adjustment, and Burden Sharing: A Unified Framework. Princeton, N.J.: Princeton University, Department of Economics.

Easterly, William. 1999. "How Did Highly Indebted Poor Countries Become Highly Indebted?-Reviewing Two Decades of Debt Relief.” Policy Research Working Paper 2225. World Bank, Development Research Group, Washington, D.C.

Eaton, Jonathan, and Raquel Fernandez. 1995. “Sovereign Debt.” In Gene M. Grossman and Kenneth S. Rogoff, eds., Handbook on International Economics. Vol. 3. North Holland: Elsevier.

Hansen, Hendrik, and Finn Tarp. 2000. “Aid Effectiveness Disputed.” Journal of International Development 12(3): 375-98.

. 2001. “Aid and Growth Regressions.” Journal of Development Economics 64(2): 545-68. 
Renard, Robrecht, and Danny Cassimon. 2001. "On the Pitfalls of Measuring Aid.” WIDER Discussion Paper 2001/69. United Nations University/World Institute for Development Economics Research, Helsinki.

Sachs, Jeffrey, and Andrew Warner. 1995. "Economic Reform and the Process of Global Integration.” Brookings Papers on Economic Activity (1): 1-118.

World Bank. 1998. Assessing Aid-What Works, What Doesn't Work, and Why. World Bank Policy Research Report. New York: Oxford University Press.

- 2000. Can Africa Claim the $21^{\text {st }}$ Century? Washington, DC.

. Various issues. Global Development Finance. Washington, D.C. 


\section{Center for Global Development Working Papers}

No. 1, January 2002

No. 2, January 2002

No. 3, February 2002

No. 4, March 2002

No. 5, April 2002

No. 6, May 2002 privatization,

No. 7, May 2002

No. 8, June 2002

No. 9, August 2002

No. 10, Sept. 2002

No. 11, October 2002

No. 12, October 2002

No. 13, October 2002

No. 14, October 2002

No. 15, October 2002

No. 16, October 2002
Inequality Does Cause Underdevelopment: New Evidence, William Easterly

HIV/AIDS and the Accumulation and Utilization of Human Capital in Africa, Amar Hamoudi and Nancy Birdsall

External Advisors and Privatization in Transition Economies, John Nellis

The Cartel of Good Intentions: Bureaucracy versus Markets in Foreign Aid, William Easterly

Intellectual Property and the Availability of Pharmaceuticals in Developing Countries, Jean O. Lanjouw

Winners and Losers: Assessing the distributional impacts of

John Nellis and Nancy Birdsall

Commodity Dependence, Trade, and Growth: When 'Openness' is Not Enough, Nancy Birdsall and Amar Hamoudi.

Financial Crises and Poverty in Emerging Market Economies, William Cline

An Identity Crisis? Testing IMF Financial Programming, William Easterly

Solutions when the Solution is the Problem: Arraying the Disarray in Development, $\quad$ Lant Pritchett and Michael Woolcock

What did structural adjustment adjust? The association of policies and growth with repeated IMF and World Bank adjustment loans, William Easterly

Asymmetric Globalization: Global Markets Require Good Global Politics, Nancy Birdsall

Low Investment is not the Constraint on African Development, Shantayanan Devarajan, William Easterly, Howard Pack

An Index of Industrial Country Trade Policy toward Developing Countries, William R. Cline

Tropics, Germs, and Crops: How Endowments Influence Economic Development, William Easterly and Ross Levine

Do As I Say Not As I Do: A Critique Of G-7 Proposals On Reforming The MDBs, Devesh Kapur 
No. 17, October 2002

No. 18, Nov. 2002

No. 19, Dec. 2002

No. 20, December 2002

No. 21, December 2002

No. 22, January 2003

No. 23, February 2003

No. 24, February 2003

No. 25, February 2003

No. 26, March 2003

No. 27, May 2003

No. 28, July 2003

No. 29, April 2003

No. 30, July 2003

No. 31, August 2003

No. 32, September 2003
Policy Selectivity Foregone: Debt and Donor Behavior in Africa, Nancy Birdsall, Stijn Claessens and Ishac Diwan

Private Sector Involvement in Financial Crisis Resolution:

Definition, Measurement, and Implementation, William R. Cline

Do Rich Countries Invest Less in Poor Countries Than the Poor Countries Themselves?, Michael A. Clemens

World Bank capital neither complements nor substitutes for private capital, Michael A. Clemens

From Social Policy to an Open-Economy Social Contract in Latin America, Nancy Birdsall

Global Economic Governance and Representation of Developing Countries: Some Issues and the IDB Example, Nancy Birdsall

The Millennium Challenge Account: How much is too much, how long is long enough?, Michael A. Clemens and Steve Radelet

Bootstraps Not Band-Aids: Poverty, Equity and Social Policy in Latin America, Nancy Birdsall and Miguel Szekely

Privatization in Africa: What has happened? What is to be done?, John Nellis

New Data, New Doubts: Revisiting “Aid, Policies, and Growth”, William Easterly, Ross Levine, David Roodman

National Policies and Economic Growth: A Reappraisal, William Easterly

Financing Pharmaceutical Innovation: How Much Should Poor Countries Contribute?, William Jack and Jean O. Lanjouw

Economic Policy and Wage Differentials in Latin America, Jere R. Behrman, Nancy Birdsall and Miguel Székely

The Surprise Party: An Analysis of US ODA Flows to Africa, Markus P. Goldstein and Todd J. Moss

Privatization in Latin America, John Nellis

The Anarchy of Numbers: Aid, Development, and Cross-country Empirics, David Roodman 